\title{
Chromium bioremediation potential of indigenous Bacillus pumillus isolated from river water of Bangladesh
}

\author{
Sangita Ahmed ${ }^{*}$, Rakibul Hasan², Sumaiya Aziz Khan², Razu Ahmed² \\ ${ }^{I}$ Professor, Department of Microbiology, University of Dhaka, ${ }^{2}$ MS Student, Department of Microbiology, University of Dhaka
}

\begin{abstract}
Bangladesh has achieved rapid industrialization in recent years. However, many of these industries lack proper effluent treatment plant and discharge untreated effluent laden with different heavy metals into the major rives that surround these industries, affecting the environment as well as human and animal health. Aiming to develop a sustainable effluent treatment plant, a heavy metal tolerant Bacillus pumillus isolated from polluted river water of Bangladesh was studied for its chromium bioremediation potential. Reduction of hexavalent chromium using the Sdiphenylcarbazide (DPC) method showed that whole cells of the Bacillus pumillus reduced $89.5 \%, 75 \%, 73 \%$ and $45 \%$ of $1.0,2.5,5$ and $10 \mathrm{mg} / \mathrm{L} \mathrm{Cr}$ (VI) to $\mathrm{Cr}$ (III), respectively. This bacterium reduced $100 \%$ of $20 \mathrm{mg} / \mathrm{L} \mathrm{Cr}$ (VI) to Cr(III) within 8 hours, in a growth associated pattern. A $20 \mathrm{~kb}$ plasmid was detected in this Bacillus pumillus, and loss of this plasmid did not cause complete impairment of chromium tolerance capacity, though the tolerance efficiency was reduced. The Bacillus pumillus studied in the current study therefore shows its potential to develop a sustainable chromium bioremediation method.
\end{abstract}

Keywords: Chromium, Bioremediation, Bacillus pumillus

\section{Introduction}

The heavy metal Chromium is used in different industrial purposes in Bangladesh including leather tanning, wood processing, metal polishing etc $^{1}$. Industrial processes like welding on stainless steel, melting at high temperature converts the trivalent chromium to its hexavalent state, while in case of leather tanning, chromium discharged in the environment is oxidized into hexavalent form ${ }^{2}$. Therefore, as most of these industries are situated near the river banks and many of them do not have proper effluent treatment plant, discharge of untreated waste results in high concentration of hexavalent chromium in the river water ${ }^{1,2,3}$. This not only pollutes the river water but also contaminates the aquatic life, agriculture fields, finally allowing chromium to enter human body through the food chain ${ }^{2}$.

Among the two different forms of chromium found in nature, the hexavalent form $\mathrm{Cr}(\mathrm{VI})$ is toxic, mutagenic and carcinogenic and therefore considered as a pollutant by the US Environmental Protection Agency ${ }^{4}$. Exposure to high concentration of $\mathrm{Cr}(\mathrm{VI})$ can cause potentially permanent learning and behavior disorders in children ${ }^{5}$. Consumption or exposure to chromium polluted water can cause skin, gastrointestinal, respiratory, reproductive and genetic disorders in human leading to cancer as well as death ${ }^{5}$. Accumulation of chromium in plants and animals also induce DNA damage and intense oxidative stress resulting in genotoxic and mutagenic effects ${ }^{5.6}$. Therefore, removal of chromium from water is of utmost importance given the impact on public as well as environmental health.
In recent years, transformation of toxic $\mathrm{Cr}(\mathrm{VI})$ into harmless $\mathrm{Cr}$ (III) by bacterial has gained attention worldwide as an environmental friendly and cost effective approach of chromium removal ${ }^{7,8,9,10}$. Transformation of $\mathrm{Cr}(\mathrm{VI})$ to $\mathrm{Cr}(\mathrm{III})$ allows bacteria to tolerate high concentration of chromium and has been reported by many bacterial species including Bacillus pumillus, Pseudomonas, Proteus, Acinetobacter spp., Burkholderia. The genetic basis to chromium tolerance in bacteria are chromosomal, plasmid mediated or both ${ }^{11,12,13}$.

In view of the above, the current study investigated the potential of a Chromium resistant Bacillus pumillus, isolated from the polluted river water of Bangladesh ${ }^{14}$ to transform $\mathrm{Cr}(\mathrm{VI})$ to $\mathrm{Cr}$ (III) with aim to develop a sustainable chromium bioremediation method.

\section{Material and method}

Chromium reduction by whole cells in buffer

The hexavalent chromium reduction assay was performed following method described by Ilias et al. ${ }^{15}$ (2011). Six aliquots of bacterial cells $(1.5 \mathrm{ml})$ were harvested from overnight culture of Bacillus pumillus grown in $50 \mathrm{ml}$ Lauria Bertani (LB) medium supplemented with 50ppm chromium $\left(\right.$ as $_{2} \mathrm{Cr}_{2} \mathrm{O}_{7}$ ) with $150 \mathrm{rpm}$ agitation at $37^{\circ} \mathrm{C}$. The cell pellets from each aliquote was washed twice with phosphate buffer $(100 \mathrm{mM}, \mathrm{pH}$ 7.0) and were resuspended in $0.5 \mathrm{ml}$ phosphate buffer. To initiate $\mathrm{Cr}(\mathrm{VI})$ reduction, $0.5 \mathrm{ml}$ of $\mathrm{K}_{2} \mathrm{Cr}_{2} \mathrm{O}_{7}$ of different concentrations ( $1 \mathrm{mg} /$ $\mathrm{L}, 2.5 \mathrm{mg} / \mathrm{l} ; 5 \mathrm{mg} / \mathrm{l} ; 10 \mathrm{mg} / \mathrm{l}$ and $20 \mathrm{mg} / \mathrm{L}$ ) in phosphate buffer 
was added into five different cell suspensions and one cell suspension was used as control with no addition of chromium. Followed by incubation at $37^{\circ} \mathrm{C}$ for $45 \mathrm{~min}$, supernatant from each cell suspenstion was collected and analysed for residual $\mathrm{Cr}$ (VI) determination colorimetrically following the Sdiphenylcarbazide (DPC) method ${ }^{15}$. Independent experiment was conducted in triplicates.

\section{Time course assay of Cr(VI) reduction}

The time course of growth and $\mathrm{Cr}(\mathrm{VI})$ reduction/transformation for the isolate was analysed as described by Ilias et al. (2011) ${ }^{15}$. The Bacillus pumillus was grown in $100 \mathrm{ml} \mathrm{LB}$ broth supplemented with $20 \mathrm{mg} / 1 \mathrm{~K}_{2} \mathrm{Cr}_{2} \mathrm{O}_{7}$ and was incubated at $37^{\circ} \mathrm{C}$ and $150 \mathrm{rpm}$. Samples $(1.5 \mathrm{ml})$ were withdrawn at $2 \mathrm{~h}$ intervals and were centrifuged (Eppendorf, Germany) at 10,000 rpm for 5 min. The supernatant was assayed for residual $\mathrm{Cr}(\mathrm{VI})$ concentration colorimetrically following the S-diphenylcarbazide (DPC) method. The growth of the bacteria was monitored measuring $\mathrm{OD}$ at $600 \mathrm{~nm}$.

\section{Reduction of $\mathrm{Cr}(V I)$ in cell fractions}

This experiment was conducted following the method described by Ilias et al., (2011) with slight modification. Cell pellets and culture supernatant were collected from the Bacillus pumillus grown overnight in $100 \mathrm{ml}$ of LB broth with $100 \mathrm{ppm}$ of $\mathrm{Cr}$ (as $\mathrm{K}_{2} \mathrm{Cr}_{2} \mathrm{O}_{7}$ ) at $37^{\circ} \mathrm{C}$ with orbital shaking $(150 \mathrm{rpm})$. The cell pellets was resuspended in $30 \mathrm{ml}$ phosphate buffer $(100 \mathrm{mM}, \mathrm{pH} 7.0)$ and was disrupted using sonication. Cell extract supernatant was collected by centrifugation at $14,000 \mathrm{rpm}$ at $4^{\circ} \mathrm{C}$ for $20 \mathrm{~min}$ following sonication. Cell lysate was also resuspended in $30 \mathrm{ml}$ phosphate buffer. To determine the chromium reduction activity of these cell fractions, $0.5 \mathrm{ml}$ of culture supernatant, cell extract supernatant or cell lysate was added to a reaction mixture contained $2 \mathrm{mg} / \mathrm{l} \mathrm{Cr}(\mathrm{VI})$ as $\mathrm{K}_{2} \mathrm{Cr}_{2} \mathrm{O}_{7}$ in $0.5 \mathrm{ml}$ of $100 \mathrm{mM}$ phosphate buffer, $\mathrm{pH}$ 7.0. After incubation for 1 hour at $37^{\circ} \mathrm{C}$ in water bath, residual $\mathrm{Cr}(\mathrm{VI})$ concentration was measured for each reaction mix following the DPC method, as previously described.

\section{Plasmid isolation}

For plasmid isolation method described by Brinboin and Dolly (1979) was followed with slight modification ${ }^{16}$. Overnight culture of the bacteria was harvested at $10000 \mathrm{rpm}$ and the pellets were thoroughly suspended in $100 \mu 1$ solution I ( $50 \mathrm{mM}$ glucose , 25 $\mathrm{mM}$ Tris- $\mathrm{HCl}$ and $10 \mathrm{mM}$ EDTA pH 8.0 ) following incubation at room temperature for $10 \mathrm{~min}$. Then $100 \mu \mathrm{l}$ of lysis solution $(0.2 \mathrm{~N} \mathrm{NaOH}, 1 \% \mathrm{SDS})$ was added and mixed gently. The tubes were kept on ice for 5 minutes and then $150 \mu 1$ of ice cold solution III (3M Potassium acetate, $5 \mathrm{M}$ glacial acetic acid $\mathrm{pH} 4.8$, TE buffer $10 \mathrm{mM}$ Tris- $\mathrm{HCl}$ and $1 \mathrm{mM}$ EDTA $\mathrm{pH}$ 8.0) was added and kept on ice for 5 minutes. The clear supernatant was taken into fresh Eppendorf tubes and mixed with twice the volume of cold $95 \%$ ethanol followed by incubation for 2 minutes at room temperature. The precipitated plasmid DNA was collected by centrifugation for 10 minutes at $12000 \mathrm{rpm}$. The dried plasmid DNA was dissolved in $50 \mu 1$ Tris-EDTA (TE) buffer.

\section{Plasmid curing}

This experiment was performed according to the method described by Samanta et al., (2017) ${ }^{17}$. An overnight culture of the bacteria grown in LB broth containing $100 \mathrm{ppm}$ Chromium was diluted to $10^{3}$ cells $/ \mathrm{ml}$ with LB broth containing $40 \mathrm{mg}$ Ethidium Bromide and was grown for 72 hours at $37^{\circ} \mathrm{C} 150 \mathrm{rpm}$ . The treated cells were plated on $\mathrm{LB}$ agar and incubated at $37^{\circ} \mathrm{C}$ for 24 hours. Plasmid cured colonies were selected by inoculating colonies on LB agar with and without chromium. Cured cells were recovered and plasmid profile was analyzed by agarose gel electrophoresis. The treated cells were diluted with normal saline and appropriate dilution $(0.1 \mathrm{ml})$ were plated on LB agar (with and without chromium) and incubated at $37^{\circ} \mathrm{C}$ for 24 hours. Colonies that grew on LB agar, but failed to grow on LB agar supplemented with $300 \mathrm{ppm} \mathrm{Cr}$ were selected as cured cells. These cells were recovered and subjected to further investigation.

\section{Results}

Hexavalent chromium reduction by Bacillus pumillus

Chromate reduction activities of $B$. pumillus using different chromium concentrations revealed that at $1 \mathrm{mg} / \mathrm{L} \mathrm{Cr}(\mathrm{VI})$ concentration (as $\mathrm{K}_{2} \mathrm{Cr}_{2} \mathrm{O}_{7}$ ), $89.5 \%$ hexavalent chromium was transformed (Figure 1). With increase in chromium concentration to $2.5 \mathrm{mg} / \mathrm{L}, 5 \mathrm{mg} / \mathrm{L}$ and $10 \mathrm{mg} / \mathrm{L}$, reduction of $\mathrm{Cr}(\mathrm{VI})$ was transformed to $75 \%, 73 \%$ and $45 \%$ respectively (Figure 1). No hexavalent chromium reduction was observed when concentration was $20 \mathrm{mg} / \mathrm{L}$ chromium.

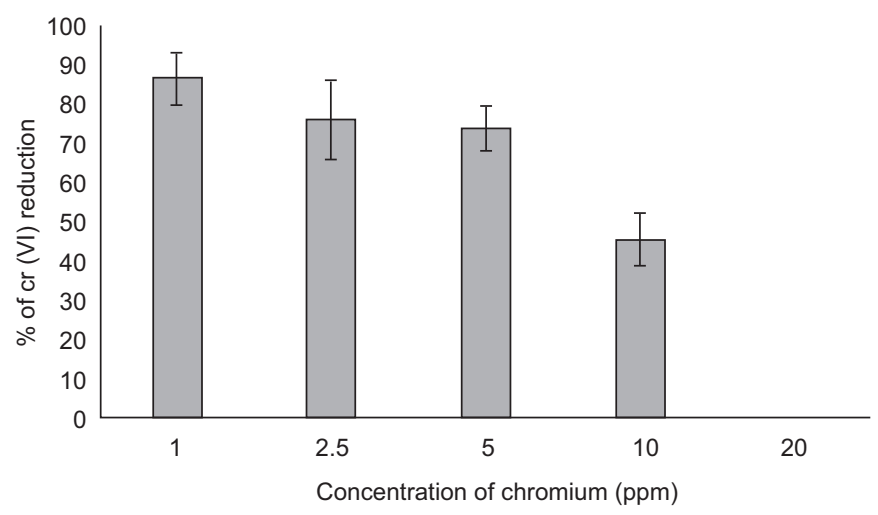

Fig. 1. Reduction of hexavalent Chromium by the Bacillus pumillus

\section{Time course of $\mathrm{Cr}$ (VI) detoxification}

Time course assay of chromium reduction showed that as the $B$. pumillus continued to grow, residual $\mathrm{Cr}(\mathrm{VI})$ decreased with time (Figure 2). Within 12 hours, $100 \%$ of the $\mathrm{Cr}(\mathrm{VI})$ present in the medium was reduced by $B$. pumillus, which suggests that chromium reduction was growth associated.

\section{Reduction of hexavalent chromium by different cell fractions}

The cell extract supernatant and culture supernatant of the $B$. pumillus reduced $18.76 \%$ and $44.64 \% \mathrm{Cr}(\mathrm{VI})$, respectively. No reduction was observed when cell lysate was used. It could be presumed that the chromium reduction activity is extracellular. 


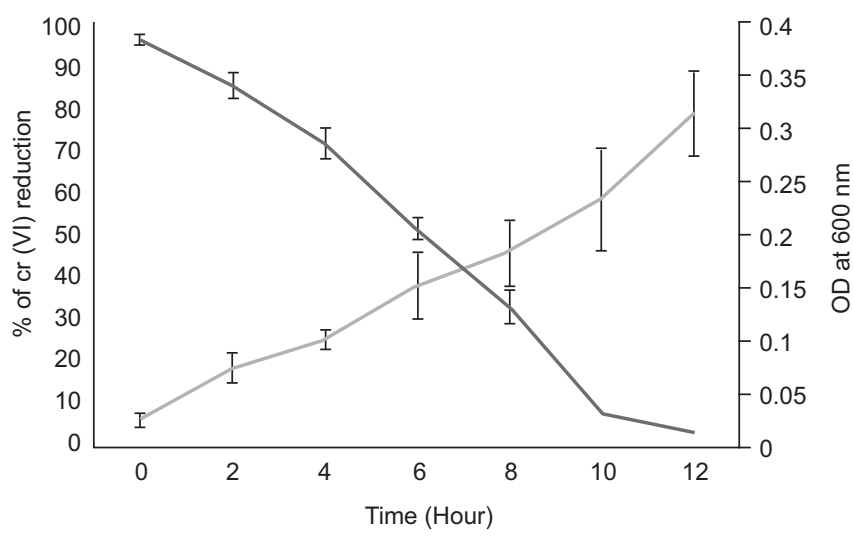

Fig. 2. Time course assay of $\mathrm{Cr}(V I)$ reduction. The blue line shows reduction of $\mathrm{Cr}(\mathrm{VI})$ and red line shows growth of the bacteria

\section{Plasmid and chromium tolerance}

A plasmid of approximately $20 \mathrm{~kb}$ in size was detected in the $B$. pumillus (Figure 4a). When this plasmid was cured using ethidium bromide, the cured cells were not as efficient as the wild type cells to tolerate high chromium concentration (Figure $4 b$ ).

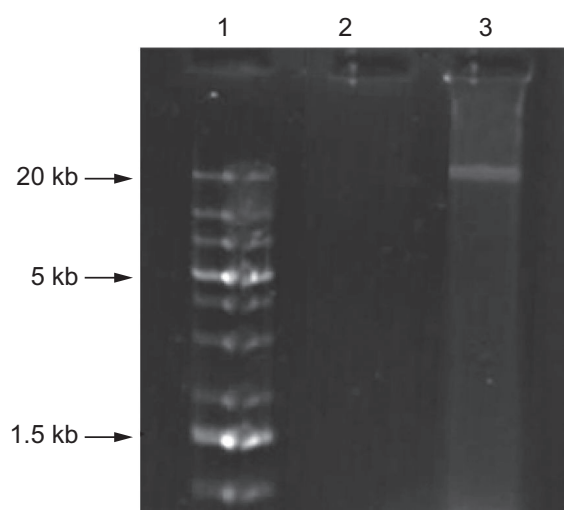

(a)

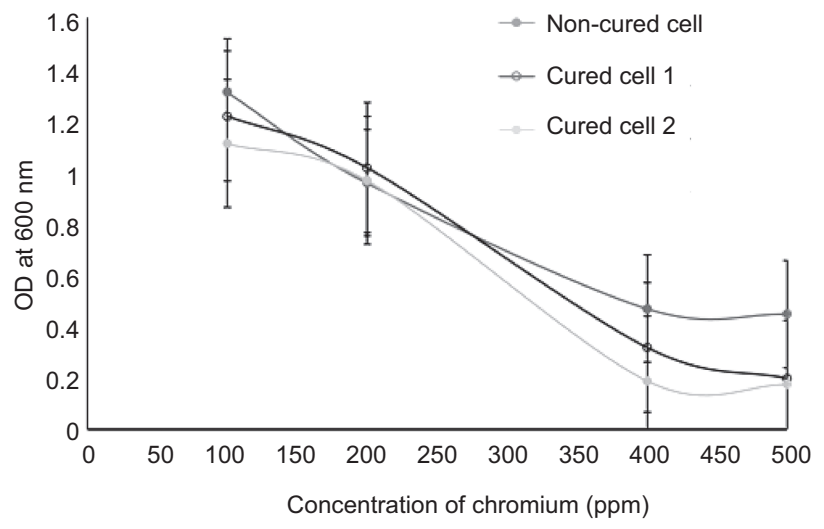

(b)

Fig. 1. Association of plasmid with chromium tolerance; (a) Agarose gel electrophoresis of plasmid DNA. From left: Lane 1$1 \mathrm{~kb}$ DNA ladder, Lane 2-negative control, Lane 3- B. pumillus. (b) Tolerance of wild-type and cured cells of B. pumillus to increased concentration of chromium. Green, blue and yellow lines indicate non-cured wild type, and growth from two different colonies from cured cells, respectively.

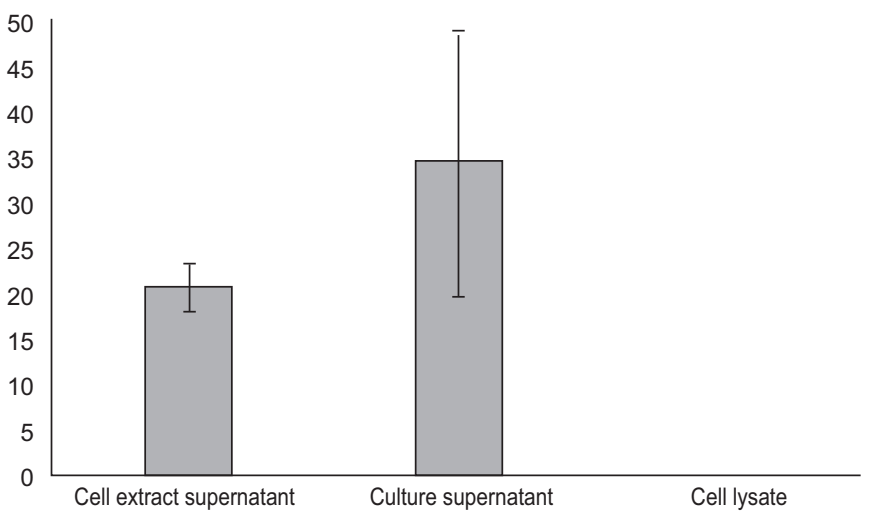

Fig. 3. Reduction of Cr(VI) by cell fractions

\section{Discussion}

This study analyzed the chromium bioremediation potential of an indigenous $B$. pumillus isolate aiming to develop a chromium bioremediation method to remove this toxic heavy metals from polluted water of Bangladesh. The bacterium could transform different concentrations of hexavalent chromium (up to10mg/ $\mathrm{ml}$ ) within 45 minutes at varying efficiencies, but failed to reduce $20 \mathrm{mg} / \mathrm{ml}$ chromium within this time period. However, complete reduction of $20 \mathrm{mg} / \mathrm{ml}$ chromium was achieved within 12 hours in a growth associated manner. This data reflects the observation by Mishra et al., (2012) who reported that an increase in incubation time from 30 minutes to 8 hour resulted in increase in $\mathrm{Cr}$ (VI) reduction from $30 \%$ to $100 \%$ by chromium tolerant Lactobacillus sp. ${ }^{19}$. Increase in incubation time also increased $\mathrm{Cr}(\mathrm{VI})$ reduction by $P$. entomophila MAI4 significantly ${ }^{20}$. It shows that the concentration of hexavalent chromium and amount of cells present in the experiment condition influence reduction of hexavalent chromium by the B. pumillus. This concentration dependent $\mathrm{Cr}(\mathrm{VI})$ reduction is possibly due to the mutagenic and toxic effects of high concentration of $\mathrm{Cr}(\mathrm{Vi})$ on bacterial cell. Bacterial cells might initially need to adjust to the chromium toxicity before initiating its reduction reaction until the growth was increased to reduce chromium with more efficiency. Similar observation was reported by Rafiqullqh et al., who showed that chromium tolerant Staphylococcus aureus and Pediococcus pentosaceus, reduced $100 \%$ hexavalent chromium within 24 hours $^{21}$.

Several researchers reported a direct association between plasmid and its tolerance to different heavy metals including chromium $^{17,22,23}$. In many studies, loss of plasmid completely disrupted tolerance to heavy metals ${ }^{17}$. The B. pumillus. investigated in the current study also harbors a plasmid, however unlike other studies, curing of this plasmid did not cause complete inhibition of chromium tolerance. Rather chromium tolerance efficiency of the plasmid cured cells was decreased as compared to the wild-type cells. This suggests that in this B. pumillus, genes associated with chromium tolerance are not solely present on 
plasmid, rather they are distributed on both chromosomes and plasmids. Similar distribution of heavy metal tolerance genes has been observed in R. sphaeroides, which had its 375 heavy metal resistance genes distributed on the chromosome as well as plasmids $^{24}$.

The current study analyses the potential of an indigenous, novel chromium tolerant bacteria for chromium bioremediation application. Detailed study on this isolate might enable developing an economic and efficient effluent treatment plant to remove toxic Chromium from tannery effluents, hence preventing water pollution and ensuring supply of safe water in Bangladesh.

\section{Acknowledgment}

This study was funded by the Ministry of Science and Technology, Government of the People's Republic of Bangladesh and University Grant Commission, Bangladesh.

\section{References}

1. Uddin MJ and Jeong YK. 2021. Urban river pollution in Bangladesh during last 40 years: potential public health and ecological risk, present policy, and future prospects toward smart water management. Heliyon. 7(2): 06107.

2. Saha R, Nandi R and Saha B. 2011. Sources and toxicity of hexavalent chromium, $J$ Coord Chem. 64(10): 1782-1806.

3. Biswas S, Rahman Md, Alim-Ul Bahar Md and Debnath S. 2015. Status of heavy metal in the peripheral rivers around Dhaka city (April 12, 2015). OIDA Int J Sust Dev. 8(2):39-44.

4. U.S. Environmental Protection Agency (USEPA). 2012. Basic information about chromium in drinking water. Retrieved from https://www.epa.gov/ sdwa/chromium-drinking-water.

5. Wilbur S, Abadin H and Fay M. 2012. Health Effects In Toxicological Profile for Chromium (Wilbur S, Abadin H, Fay M, Yu D, Tencza B, Ingerman L, Klotzbach J and James S). Agency for Toxic Substances and Disease Registry (US), Atlanta (GA).

6. Wakeel A, Xu M, Gan Y. 2020. Chromium-Induced Reactive Oxygen Species Accumulation by Altering the Enzymatic Antioxidant System and Associated Cytotoxic, Genotoxic, Ultrastructural, and Photosynthetic Changes in Plants. Int J Mol Sci. 21(3):728. doi: 10.3390/ijms21030728.

7. Nupur SH, Rayhan A and Ahmed S. 2020. Bacteria with heavy metal bioremediation potential isolated from the polluted river water of Bangladesh. IOSR J Biotech Biochem. 6(1):6-14.

8. Kabir MM, Fakhruddin ANM, Chowdhury MAZ. 2018. Isolation and characterization of chromium(VI)-reducing bacteria from tannery effluents and solid wastes. World J Microbiol Biotechnol. 34(126): https://doi.org/ 10.1007/s11274-018-2510-z.

9. Maria SS, Dorairaj S, Gnanaprakasam AR and Kathirvelu B. 2020. Isolation and identification of chromium reducing bacteria from tannery effluent. J King Saud Univ- Sci, 32(1): 265-271. https://doi.org/10.1016/ j.jksus.2018.05.001.

10. Kamala-Kannan S and Lee KJ. 2008. Metal Tolerance and Antibiotic Resistance of Bacillus pumillus species Isolated from Sunchon Bay Sediments, South Korea. Biotechnology. 7: 149-152.

11. Verma T, Garg S and Ramteke P. 2009. Genetic correlation between chromium resistance and reduction in Bacillus pumillus brevis isolated from tannery effluent. J App Microbiol. 107(5):1425-1432. doi:10.1111/ j.1365-2672.2009.04326.

12. Sofia M, Anatoliy P and Mayya P. 2018. Chromium resistance genetic element flanked by XerC/XerD recombination sites and its distribution in environmental and clinical Acinetobacter strains. FEMS Microbiology Letters. 365(8). https://doi.org/10.1093/femsle/fny047

13. Sultan S \& Hasnain S. 2005. Plasmid mediated chromate resistance in bacteria isolated from industrial waste, PakJ Biol Sci. 8(12): 1771- 1777.

14. Shammi T and Ahmed S. 2014. Heavy Metal Tolerance and Antibiotic resistance of Bacillus pumillus sp. isolated from two major rivers in Bangladesh. Bang J Microbiol. 30(1\&2):17-22.

15. Ilias M, Rafiqullah IF, Debnath BC, Mannan KSB, Hoq MM. 2011. Isolation and characterization of chromium(VI)-reducing bacteria from tannery effluents. Ind J Microbiol. 51(1): 76-78.

16. Birnboin HC and Dolly J. 1979. A rapid alkaline extraction procedure for screening recombinant plasmid DNA. Nucl Acids Res. 7:1513-1523.

17. Samanta A, Bera P, Khatun M, Sinha C, Pal P, Lalee A and Mandal A. 2017. An investigation on heavy metal tolerance and antibiotic resistance properties of bacterial strain Bacillus pumillus sp. isolated from municipal waste. J Microbiol Biotechnol Res. 2:178-189.

18. Sambrook J, Fritschi EF and Maniatis T. 1989. Molecular cloning: A laboratory manual. Cold spring Harbor Laboratory Press, New York.

19. Mishra R, Sinha V, Kannan A and Upreti RK. 2012. Reduction of Chromium-VI by Chromium Resistant Lactobacilli: A Prospective Bacterium for Bioremediation, Toxicol Int, 19(1). 25-30. doi:10.4103/ 0971-6580.94512).

20. Wani AA, Wahid S, Khan MSA, Rafi N and Wahid N. 2019. Investigation of the role of chromium reductase for $\mathrm{Cr}(\mathrm{VI})$ reduction by Pseudomonas species isolated from Cr (VI) contaminated effluent. Biotech Res Innov. 3(1):38-46. https://doi.org/10.1016/j.biori.2019.04.001

21. Rafiqullah I, Hossain A, Ilias M and Hoq M. 2008. Chromium(VI) Reducing Native Microorganisms for Remediation of Chromium Ecotoxicity in Environment of Bangladesh. Bang J Sci Indust Res. 43(4):455466. https://doi.org/10.3329/bjsir.v43i4.2236

22. Moretto JAS, Braz VS, Furlan JPR, Stehling EG. 2019. Plasmids associated with heavy metal resistance and herbicide degradation potential in bacterial isolates obtained from two Brazilian regions. Environ Monit Assess. 191(5):314. doi: 10.1007/s10661-019-7461-9. PMID: 31037401.

23. Sevim A and Sevim E. 2015. Plasmid mediated antibiotic and heavy metal resistance in Bacillus pumillus strains isolated from soils in Rize, Turkey. J Nat and App Sci. 19(2):133-145.

24. Johnson H, Cho H and Choudhary M. 2019. Bacterial Heavy Metal Resistance Genes and Bioremediation Potential. Comp Mol Biosci, 9: 112. doi: $10.4236 / \mathrm{cmb} .2019 .91001$. 